\title{
THE TESTOSTERONE-CORTISOL MODEL AS A WAY TO UNDERSTAND THE MECHANISM OF ALCOHOL DEPENDENCE WHICH STARTED IN PUBERTY
}

10.36740/WLek202010118

\author{
Ivan Yu. Lobanov \\ STATE INSTITUTION “INSTITUTE OF NEUROLOGY, PSYCHIATRY AND NARCOLOGY OF THE NATIONAL ACADEMY OF MEDICAL SCIENCES OF UKRAINE”, \\ KHARKIV, UKRAINE
}

\begin{abstract}
The aim: Is to analyze the role of testosterone and cortisol in the mechanism of alcohol use disorders formation for further development of early diagnosis and prevention methods. Materials and methods: 155 adolescents at the preclinical stages of alcohol use disorders formation and 87 young patients with diagnosed alcohol dependence were studied by enzyme-linked immunoassay techniques.

Results: The analysis of the obtained materials shows that the onset of search behaviors on alcohol consumption, frequency and alcohol abuse in adolescents occur with the participation of age-related processes of somatic puberty and the related syndromes of hormonal tension. The phasing of development and course of alcoholic disease includes pubertal age and alcohol-induced changes in the internal environment of the body. There is an increase in the concentration of testosterone and cortisol that initiates interest in alcohol first, and then under the influence of its toxic effect, the level of these hormones decreases. It should be borne in mind that significant differences in hormone concentrations were observed within the regulatory framework.

Conclusions: An increase of testosterone and cortisol levels in puberty, combined with regular consumption of alcohol, may indicate a risk of addiction early. Further decrease of the levels of these hormones along with an increase of the frequency of alcohol consumption may be an early diagnostic feature of the alcohol use disorders.
\end{abstract}

KEY WORDS: alcohol use disorders, puberty, testosterone, cortisol

Wiad Lek. 2020;73(10):2204-2208

\section{INTRODUCTION}

It was approved that acute and chronic effects of ethanol reduce testosterone $(\mathrm{T})$ levels in male blood plasma due to a direct inhibitory effect on steroidogenesis and a decrease in testicular receptors $[1,2]$. Alcoholic lesions of Leydig cells of male gonads were detected at clinical stages of alcohol dependence (AD) [1,3]. Later on, chronic alcohol intoxication (AI) is already depleting the system of central regulation of sex hormones [4,5]. Early manifestations of lesions of the male reproductive glands have the ability to reverse; further there is atrophy of the gonads [6,7] and irreversible suppression of sexual function $[8,9]$. Even episodic alcohol consumption has a significant inhibitory effect on the hypothalamic-pituitary component of the male reproductive system [10].

For patients with $\mathrm{AD}$, it is mandatory to reduce the level of $\mathrm{T}$ in the blood and increase the content of cortisol (F) [1114]. Routine administration of ethanol to rats for 6 months reduced gonadal mass by $30 \%$ [15]. Comparison of alcohol abusers revealed a rapid onset of $\mathrm{AD}$ symptoms (within 3 years) in individuals with reduced androgen status [16]. The author concludes that patients with reduced androgen status are less protected from the toxic effects of ethanol.

The results of special pathoanatomical studies [17] indicate a high frequency of morphological changes on the part of the external genitalia in persons abusing alcohol or drugs during their lifetime.

Sexual behavior is subject to deviation when there has been a prenatal exposure to alcohol, stress, or combinations thereof [18]. Such prenatal adverse effects in the future (in adulthood) cause initially low and then persistent low levels of $\mathrm{T}$ in blood.

In a basic review of research, it is emphasized that sex hormones throughout the life of an individual create both permanent and periodic "structural-organizational" and "functionally-activative" effects on the human brain and its behavior, in particular in the perinatal period of development [19]. There is also a certain sequence of increases in sex hormones and $\mathrm{F}$ in the blood in adolescence. T modulates the activity of addictive behavior. It also affects the rate of breakdown of alcohol in the body [20]. The hormone promotes both the initiation of adolescent puberty and the onset of alcohol abuse during puberty [21].

It is proved that the timing of the onset and the intense progression of puberty are of prognostic importance for the initiation or intensification of alcohol abuse in adolescence [22]. The sooner somatic puberty begins, the sooner boys and girls start smoking tobacco and drinking alcohol and other surfactants [23-25]. It is noteworthy that castration of hamsters before the onset of puberty leads to a dramatic reduction in aggressive behavior and reduces the risk of $\mathrm{AD}$ [26]. 
Table I. The content of hormones in the serum of adolescents at the stages of development of AUD, nmol/l

\begin{tabular}{cccccc}
\hline Hormone & \multicolumn{5}{c}{ Amount } \\
\cline { 2 - 6 } & $\begin{array}{c}\text { Group I } \\
(\mathbf{n}=\mathbf{3 4 )}\end{array}$ & $\begin{array}{c}\text { Group II } \\
(\mathbf{n}=\mathbf{4 7})\end{array}$ & $\begin{array}{c}\text { Group III } \\
(\mathbf{n}=\mathbf{2 6})\end{array}$ & $\begin{array}{c}\text { Group IV } \\
(\mathbf{n}=\mathbf{2 9})\end{array}$ & $\begin{array}{c}\text { Group V } \\
(\mathbf{n}=\mathbf{1 9})\end{array}$ \\
\hline$T$ & $8.57 \pm 3.12^{1)}$ & $12.59 \pm 4.39^{1)}$ & $22.15 \pm 5.83^{1)}$ & $15.98 \pm 4.96^{1)}$ & $18.43 \pm 5.74^{1)}$ \\
\hline$F$ & $411.19 \pm 128.14$ & $543.78 \pm 159.47^{2)}$ & $521.75 \pm 130.87^{2)}$ & $415.32 \pm 160.56^{3)}$ & $435.21 \pm 126.70^{3)}$ \\
\hline
\end{tabular}

1) - differences with all other groups are statistically significant $(p<0.05)$;

2) - statistically significant difference with group I $(p<0.05)$;

3) - statistically significant differences with groups II and III ( $p<0.05)$.

\begin{tabular}{cccccc}
\hline Ratio & $\begin{array}{c}\text { Group I } \\
(\mathbf{n = 3 4 )}\end{array}$ & $\begin{array}{c}\text { Group II } \\
(\mathbf{n}=\mathbf{4 7})\end{array}$ & $\begin{array}{c}\text { Group III } \\
(\mathbf{n}=\mathbf{2 6})\end{array}$ & $\begin{array}{c}\text { Group IV } \\
(\mathbf{n}=\mathbf{2 9 )}\end{array}$ & $\begin{array}{c}\text { Group V } \\
(\mathbf{n}=\mathbf{1 9 )}\end{array}$ \\
\hline F/T & $52.96 \pm 23.87$ & $46.43 \pm 14.56$ & $25.44 \pm 10.72^{*}$ & $27.21 \pm 10.71^{*}$ & $24.38 \pm 5.22^{*}$ \\
\hline
\end{tabular}

* - statistically significant differences with groups I and II ( $p<0.05)$.

\begin{tabular}{cccc}
\hline \multirow{2}{*}{ Hormone } & \multicolumn{3}{c}{ Amount } \\
\cline { 2 - 4 } & Average norm & Withdrawal syndrome & After WS \\
\hline $\mathrm{F}$ & $490.00 \pm 260.00$ & $512.00 \pm 141.72^{2)}$ & $392.64 \pm 92.12^{1)}$ \\
\hline $\mathrm{T}$ & $33.02 \pm 21.50$ & $9.01 \pm 1.25^{1)}$ & $7.76 \pm 2.15^{1)}$ \\
\hline $\mathrm{F} / \mathrm{T}$ & 14.84 & $56.83^{1)}$ & $50.60^{1)}$ \\
\hline
\end{tabular}

1) - statistically significant differences with norm $(p<0.05)$;

2) - statistically significant differences between the first and second examinations $(p<0.05)$.

As the norm used indicators calculated by the Department of Biochemistry of SI "INPN NAMSU".

Healthy men (students) have higher T level content associated with higher levels of alcohol use [27]. At the same time, men with high $\mathrm{T}$ levels are more likely to consume ethanol and are more likely to become addicted to alcohol than individuals with low T levels $[28,29]$.

The biological effects of $\mathrm{T}$ are determined not only by its absolute values in the blood, but also by the level of sensitivity of tissues and target organs to this hormone [30].

Thus, biological (hormonal) factors cause a high risk of developing pathological attraction to substances, activities or objects during adolescence. Androgens determine the attitude of humans and animals to alcohol. Male sex hormones are involved in the occurrence of states of substance, object and action dependence and through involvement of structures of the opioid brain system. Ethanol is undoubtedly a gonadotoxic substance.

The dynamics and intensity of clinical manifestations of alcohol use disorders (AUD), the severity of the complications that arise and the pathogenic consequences, may be due to puberty and age-related changes in the adaptation and compensatory capacity of the adolescent organism. The leading tasks of modern addictology are the questions of finding reliable biological (including hormonal) markers for assessing the degree of risk of clinical manifestations of alcohol and other addictions, their early diagnosis and prevention.

\section{THE AIM}

The working hypothesis is that AUD, its negative effects and complications are procedural phenomena that began in the perinatal period. It goes through the life of an addict, manifests at puberty, with the participation of physiological changes in metabolic status during somatic puberty and early onset of exotoxicosis at puberty - alcohol, tobacco, narcotic or other intoxication. The testosterone-cortisol component of early onset AUD development should be studied in order to further search for markers for early diagnosis at the preclinical stage.

\section{MATERIALS AND METHODS}

Enzyme-linked immunoassay study of $\mathrm{T}$ and $\mathrm{F}$ content included 155 male students aged 15 to 19 years, divided into 5 groups (group I - abstinents, they do not consume alcohol, group II - occasional consume no more than once a month, group III - regularly consuming alcohol (2-14 times a month), group IV - with some signs of mental dependence (addiction), group V - with some signs of physical dependence). Additionally, similar studies were conducted on a sample of patients with $\mathrm{AD}$ (87 male, 21-33 years old) at the stages of alcohol withdrawal syndrome (WS) and after cupping of it (group VI, clinical). Groups were seen as a continuum. The processing was carried out with the non-parametric U Mann-Whitney criterion on R-Studio.

\section{RESULTS}

The lowest content of $\mathrm{T}$ in the blood was found in adolescents who did not consume alcohol $(8.57 \pm 3.12 \mathrm{nmol} / \mathrm{l})$ (Table I). Such concentrations of $\mathrm{T}$ are too low to provide the impe- 
tus for hormonal intensification and do not stimulate the development of alcohol motivations. This conclusion is also consistent with low content of F $(411.19 \pm 128.14 \mathrm{nmol} / \mathrm{l})$. Significant increase in the content of $\mathrm{T}$ in the serum of adolescents by $46.91 \%$ in group II and by $158.46 \%$ in group III relative to group I $(\mathrm{p}<0.05)$ is a powerful hormonal factor for the activation of complex processes of somatic puberty. It is responsible for the occurrence of testicular hormonal stress and contributes to the appearance of search behavior before drinking. The concentration in the blood of F increases in group II - by $32.25 \%$ and in group III - by $26.89 \%(\mathrm{p}<0.05)$ relative to group I.

Thus, already in the preclinical stages of addictive disorder, there is a link between the physiological increase of $T$ in blood, the increase in the level of $\mathrm{F}$ and the appearance of alcohol search behavior. This defined the age range in which the teenager searches for a means of relieving frustration that is the beginning of drinking. Further, at the stages of formation of states of AD (groups IV and V) toxic effects of ethanol begin to accumulate, which leads to the transformation of hormonal (testicular) homeostasis. This transformation is manifested by a decrease of $\mathrm{T}$ content relative to the highest levels in group III by $27.86 \%$ in group IV, and by $16.79 \%$ in group V.

According to the content of $\mathrm{T}$ the level of $\mathrm{F}$ was decreased too by $23.62 \%$ in group IV and $19.96 \%$ in group V (relative to the highest concentrations in group II). This indicates a positive anti-stress effect of regular alcohol consumption during adolescence, which further ensures that $\mathrm{AD}$ is fixed.

The F/T ratio (Table II) showed that abstinents (group I) and those who consume alcohol sporadically (group II) have its highest rate due to the high content of $\mathrm{F}$ and low $\mathrm{T}$ (52.96 \pm 23.87 and $46.43 \pm 14.56$ respectively). This reflects the features of premorbid somatic and sexual development, the adaptation processes and the state of their hormonal support outside the transformative influence of AI. In the subsequent stages of alcohol consumption (groups III, IV and $\mathrm{V}$ ) the F/T ratio decreases. This probably shows the important role of this indicator in the fixation of AUD. Hormonal cortisol-testosterone balance in the body of a teenager is already achieved through regular AI.

The concentration of $\mathrm{T}$ at WS was almost four times lower than the average, and the F/T ratio was almost four times higher $(\mathrm{p}<0.05)$ (Table III).

In the treated patients with $\mathrm{AD}$, as a result of WS relief, a decrease in $\mathrm{F}$ excretion was observed by $30.40 \%(\mathrm{p}<0.05)$. Probably this can be explained by the process of the reverse development of WS, which was a powerful frustrating factor for the patient with AD. T concentrations and major stress hormone F immediately after treatment continued to decrease: $\mathrm{T}$ from $(9.01 \pm 1.25)$ to $(7.76 \pm 2.15) \mathrm{nmol} / \mathrm{l}$ (by $13.87 \%) ; \mathrm{F}$ from $(512.00 \pm 141.72)$ to $(392.64 \pm 92.12) \mathrm{nmol} / \mathrm{l}$ (by $23.31 \%$ ). This may indicate the depletion of endocrine homeostasis, $\mathrm{F}$ and $\mathrm{T}$ deficiency in the body under the influence of early and prolonged (for 1-15 years) alcohol abuse. Perhaps, it may take a long period of complete sobriety to normalize the cortisol and testosterone levels of homeostasis in patients with AD.

\section{DISCUSSION}

The data obtained generally confirm the important role of the shift of $\mathrm{T}$ concentration as a risk factor for the formation and rapid formation of AUD [31,32]. This is consistent with the fact that the hyperfunction of the sex glands led to an acceleration of the rate of development of dependence [33]. The author suggests that premorbid hypertestosteronemia can be a prognostic sign of the development of addiction, even with episodic contact with surfactants. Further increasing of AI causes changes in the endocrine system, fixes the state of dependence on alcohol and forms a new functional system of life of the organism after P. K. Anokhin [34]. Ethanol primarily inhibits the production of sex steroid hormones, which secondarily (after the phase of compensatory growth of pituitary gonadotropin excretion) leads to depletion of endocrine function, decrease in spermatogenesis, disorders of sexual identification and behavior, social and functional disorders. This study showed that the $\mathrm{T}$ and $\mathrm{F}$ levels increase within normal limits in combination with systematic use of alcohol may be an early prognostic sign of the AUD with the beginning in puberty.

\section{CONCLUSIONS}

Founded relations between the level of T, F in the blood and the AI in groups I-V (which reflect the stages of AUD formation) has theoretical and clinical significance. On the one hand, increasing of $\mathrm{T}$ content in the body of a teenager is a metabolic prognostic marker of a risk of early developing of AUD, and on the other hand, ethanol itself adversely affecting hormonal metabolism in the subsequent stages of ontogeny secondary changes in $\mathrm{T}$ and $\mathrm{F}$ content. The testosterone-cortisol component of the onset of AUD is likely to be related to the pubertal period. It should be noted that all differences are observed within (lower and upper limits) of the norm.

The occurrence of AUD in adolescents occurs with the participation of physiological pubertal increase of $T$ in the blood. This intrinsic stress is also manifested by the corresponding increase in the blood content of $\mathrm{F}$ (a leading stress hormone). It is responsible for the occurrence of a wide range of psycho-emotional and behavioral disorders that relate to stress-adaptive syndrome in adolescents. The identified changes create the need to find a simple energy-efficient strategy for regulating well-being and initiate the occurrence of interest in drinking alcohol in adolescents of II and III groups, the occurrence of such use: first occasionally, and then regularly.

Adolescence in the process of regular alcohol consumption in the III, IV, V groups weakens the mental, emotional and negative component of the state of stress. At the same time, in the III, IV, V groups, under the influence of chronic $\mathrm{AI}$ on the gonads, the production of $\mathrm{T}$ in the body decreases. This forms the metabolic basis for the occurrence of a state of addiction as early as adolescence. In the group of patients with $\mathrm{AD}$ aged 21-33 years with a greater experience of alcohol abuse, there are also more significant toxic 
effects: reducing the level of $\mathrm{T}$ in the body. The above is most significant in the ratio of hormones: the F/T factor in groups I and II was higher, and in groups III, IV, V, and VI it decreased, fixing a new alcohol-distorted metabolic homeostasis in the body. The above mechanism works, initially, as a certain sequence of relationships between the main male hormone $(\mathrm{T})$ and the main stress hormone $(\mathrm{F})$ precisely during the period of unstable equilibrium and the formation of numerous functions that is in puberty. In the future, at a more advanced age, they are joined by more complex hormonal changes. The fixation of AUD is based on the anti-stress effects of ethanol, with which the person seeks to restore mental and physical comfort.

Given the important role of testosterone and cortisol in providing complex energy, metabolic and adaptive processes in the body, it is possible to assume the participation of revealed changes in hormonal homeostasis in the occurrence and fixation of the state of AUD in adolescence. Undoubtedly, in the formation of AUD other pathogenetic (endocrine and nonendocrine) changes are important.

\section{REFERENCES}

1. Astrakhantsev A.F. Struktura muzhskikh polovykh zhelezv postnatalnom ontogeneze [The structure of the male sex glands in postnatal ontogenesis]: Avtoref. diss. d-ra med. nauk. Ryazansk. gos. med. un-t. im. ak. I. P. Pavlova. Ryazan, 1996; 48. (in Russian).

2. Kolupaev G.P., Yakovlev V.A. Kliniko-gormonalnye korrelyatsii u patsientov $s$ khronicheskim alkogolnym opyaneniem [Clinical and hormonal correlations in patients with chronic alcohol intoxication]. Zh. Nevrol. Psikhiatr. Im. S. S. Korsakova. 1985;85(11):1709-12. (in Russian).

3. Ukhov Yu.I., Astrakhantsev A.F., Kovchegov B.N. Znachenie morfologicheskoy otsenki sostoyaniya semennikov $v$ diagnostike khronicheskoy intoksikatsii alkogolem [The value of the morphological assessment of the state of the testes in the diagnosis of chronic alcohol intoxication]. Mater. II-go Vseross. sezda sudeb-nykh medikov: tezisy dokladov. Irkutsk-M. 1987;198-9. (in Russian).

4. von der Pahlen B., Sarkola T., Seppa K. et al. Testosterone, 5a-dihydrotestosterone and cortisol in men with and without alcoholrelated aggression. J Stud Alcohol. 2002;63(5):518-26.

5. Sher L. Etiopathogenesis of depression in patients with alcoholism: role of changes in thyroid function. Med Hypotheses. 2002;59(2):167-9.

6. Liu P.Y., Turner L., Rushford D. et al. Efficacy and safety of recombinant human follicle stimulating hormone (Gonal-F) with urinary human chorionic gonadotrophin for induction of spermatogenesis and fertility in gonadotrophin-deficient men. Hum Reprod. 1999;14(6):1540-5.

7. Bondarenko V.A. Gormony sistemy gipofiz-gonady i ikh modulyatory $\mathrm{v}$ terapii narusheniy spermatogeneza u muzhchin [Hormones of the pituitary-gonadal system and their modulators in the treatment of spermatogenesis disorders in men]. Int Med J. 2000;3:39-42. (in Russian).

8. Wright H.J., Gavaler J.S., Van Thiel D.H. Effects of alcohol on the male reproductive system. Alcohol Health Res World. 1991;15(2):110-4.

9. Kuzmenko T.S. Kachestvennye izmeneniya gomeostaza v svyazi s velichinoy deystvuyushchego faktora i ikh rol v porozhdenii ili oslablenii raznogo roda zavisimostey [Qualitative changes in homeostasis in connection with the magnitude of the acting factor and their role in the generation or weakening of various kinds of dependencies]. Narkologiya. 2004;7:55-61. (in Russian).
10. Greene L.W., Hollander C.S. Alcohol and the hypothalamus. Prog Biochem Pharmacol. 1981;18:15-23.

11. Coiro V., Vescovi P.P. Alcoholism abolishes the effects of melatonin on growth hormone secretion in humans. Neuropeptides. 1998;32(3):211-4.

12. Waldhaus W. Auswirkungen des Alcohol sauf das Endocrinium. Actamed austr. 1984;67-9.

13. Endo M., Endo J., Note S. et al. Pituitary dwarfism and alcohol sensitivity. Biol Psychiatry. 1983;18(7):839-41.

14. Thadani P.V. Effect of maternal ethanol ingestion on control of growth hormone secretion by biogenic amines in rat offspring. Neuroendocrinology. 1984;38(4):317-21.

15. Hauk H., Scheider M., Born H.Y. et al. Development of ethanol-induced testicular atrophy in the rat. Actaendocrinol. 1983;102(252):142.

16. Dvorik S.V. Androgennaya aktivnost pri khronicheskom alkogolizme: Kliniko-patogeneticheskiy i terapevticheskiy aspekty [Androgenic activity in chronic alcoholism: Clinical, pathogenetic and therapeutic aspects]: Avtoreferat dis. kand. med. nauk. Moskow. 1984; 23. (in Russian).

17. Dmitrieva 0.A., Sherstyuk B.V. Morfofunktsionalnye izmeneniya muzhskikh naruzhnykh polovykh organov pri alkogolizme i narkomanii [Morphofunctional changes in the male external genital organs with alcoholism and drug addiction]. Sudebno-meditsinskaya ekspertiza. 2003;46(1):18-20. (in Russian).

18. McGivern R.F., Barron S. Influence of prenatal alcohol exposure on the process of neurobehavioral sexual differentiation. Alcohol Healthand Res World. 1991;15(2):115-25.

19. Lenz B., Muller C.P., Stoessel C. et al. Sex hormone activity in alcohol addiction: Integrating organizational and activational effects. Prog Neurobiol. 2012;96(1):136-63. doi: 10.1016/j.pneurobio.2011.11.001.

20. Nakamura K., Iwahashi K., Furukawa A. et al. Acetaldehyde adducts in the brain of alcoholics. Arch Toxicol. 2003;77(10):591-3.

21. Chambers R.A., Taylor J.R., Potenza M.N. Developmental neurocircuitry of motivation in adolescence: a critical period of addiction vulnerability. Am J Psychiatry. 2003;160(6):1041-52.

22. Bratberg G.H., Nilsen T.I., Holmen T.L. et al. Sexual maturation in early adolescence and alcohol drinking and cigarette smoking in late adolescence: a prospective study of 2,129 Norwegian girls and boys. Eur J Pediatr. 2005;164(10):621-5.

23. Tschann J.M., Adler N.E., Irwin C.E. Jr. et al. Initiation of substance use in early adolescence: the roles of pubertal timing and emotional distress. Health Psychol. 1994;13(4):326-33.

24. Wilson D.M., Killen J.D., Hayward C. et al. Timing and rate of sexual maturation and the onset of cigarette and alcohol use among teenage girls. Arch Pediatr Adolesc Med. 1994;148(8) :789-95.

25. Marklein E., NegriffS., Dorn L.D. Pubertal timing, friend smoking, and substance use in adolescent girls. Prev Sci. 2009;10(2):141-50. doi: 10.1007/s11121-008-0120-y.

26. Schulz K.M., Molenda-Figueira H.A., Sisk C.L. Back to the future: the organizational-activational hypothesis adapted to puberty and adolescence. Horm Behav. 2009;55(5):597-604. doi: 10.1016/j. yhbeh.2009.03.010.

27. La Grange L., Jones T.D., Erb L. et al. Alcohol consumption: biochemical and personality correlates in a college student population. Addict Behav. 1995;20(1):93-103.

28. Eriksson C.J., Kaprio J., Pulkkinen L. et al. Testosterone and alcohol use among adolescent male twins: testing between-family associations in within family comparisons. Behav Genet. 2005;35(3):359-68. 
29. Suzuki R., Allen N.E., Appleby P.N. et al. Lifestyle factors and serum androgens among 636 middle aged men from seven countries in the European Prospective Investigation into Cancer and Nutrition (EPIC). Cancer Causes Contro. 2009; 6(20):811-21.

30. YakovlevV.A., Golovach I.I. Izmenenie gipofizarno-gonadnoy sistemy pri alkogolizme i ikh rol v prognoze zabolevaniya [Change in the pituitarygonadal system in alcoholism and their role in the prognosis of the disease]. Vrachebnoe del0. 1993;4:51-54. (in Russian).

31. Emanuele M.A. The effects of alcohol on the neuroendocrine control of reproduction. In: Halloran MM, Uddin S, Tentler JJ. Et al. Alcohol and the Endocrine System. National Institute on Alcohol Abuse and Alcoholism Research Monograph No. 23. NIH Pub. No. 93-3533. Bethesda, MD: National Institutes of Health; 1993; 89-116.

32. Darenskiy I.D., Melnikov A.V. Gormonalnye aspekty kliniki i lecheniya alkogolizma [Hormonal aspects of the clinic and treatment of alcoholism]. Okhrana psikhicheskogo zdorovya. Vladivostok. 1994: 24-28. (in Russian).

33. Gromov L.A. Teoriya prakticheskoy narkologii [Theory of practical narcology]. Likarska sprava. 2000;2:19-23. (in Russian).

34. Anokhin P. K. Ocherki po fiziologii funktsionalnykh sistem [Essays on the physiology of functional systems]. Moskva: Meditsina; 1975;448. (in Russian).

35. Muthusami K.R., Chinnaswamy P. Effect of chronic alcoholism on male fertility hormones and semen quality. Fertil Steril. 2005;84(4):919-24.
The research was carried out within the scientific research of the Department of Clinical and Social Narcology of State Institution "Institute of Neurology, Psychiatry and Narcology of the National Academy of Medical Sciences of Ukraine" (Kharkiv) "To study endocrine mechanisms of alcohol dependence formation" (state registration number 0113U001290).

\section{ORCID and contributionship:}

Ivan Yu. Lobanov: 0000-0001-7040-1668 A, D, C, D, E, F

\section{Conflict of interest:}

The Author declare no conflict of interest.

\section{CORRESPONDING AUTHOR} Ivan Yu. Lobanov

Ambulatory of Narcology

20-a Shevchenka St., 36000 Poltava, Ukraine

tel: +380505647906

e-mail: ivanlobanov.ua@gmail.com

Received: 28.10 .2019

Accepted: 05.08 .2020

A - Work concept and design, B - Data collection and analysis, C - Responsibility for statistical analysis,

D-Writing the article, $\mathbf{E}$-Critical review, $\mathbf{F}$ - Final approval of the article 